\title{
Monoclonal Antibody Pharmacokinetics in Type 2 Diabetes Mellitus and Diabetic Nephropathy
}

\author{
Gurkishan S. Chadha ${ }^{1} \cdot$ Marilyn E. Morris ${ }^{1}$
}

Published online: 26 January 2016

(C) Springer International Publishing AG 2016

\begin{abstract}
The incidence of diabetes mellitus (DM) is increasing worldwide, and both type 1 as well as type 2 DM patients are at high risk of developing diabetic nephropathy (DN). Although the effects of DM and DN have been well documented for low molecular weight proteins and albumin, there is limited information regarding the changes in the clearance of higher molecular weight proteins, including monoclonal antibodies (mAbs) and $\mathrm{IgG}$, an antibody isotype. This review compiles the available literature describing the effects of DM and $\mathrm{DN}$ on the pharmacokinetics and pharmacodynamics of $\operatorname{IgG}$ and $\mathrm{mAbs}$ and the potential mechanisms underlying the effects of $\mathrm{DM}$ and $\mathrm{DN}$ on $\mathrm{IgG} / \mathrm{mAb}$ renal and catabolic clearances. This review also highlights the role of the neonatal $\mathrm{Fc}$ receptor ( $\mathrm{FcRn}$ ) and endocytic receptors (megalin and cubilin) and the influence of cytokines on renal function and expression/function of these proteins.
\end{abstract}

Keywords Diabetes mellitus · Diabetic nephropathy · Monoclonal antibodies $\cdot \mathrm{FcRn} \cdot$ Megalin $\cdot$ Cubilin

\section{Introduction}

Diabetes mellitus (DM) is a complex chronic metabolic disturbance of carbohydrate metabolism characterized by fasting

This article is part of the Topical Collection on Molecular Drug Disposition

Marilyn E. Morris

memorris@buffalo.edu

1 Department of Pharmaceutical Sciences, School of Pharmacy and Pharmaceutical Sciences, University at Buffalo, State University of New York, 352 Kapoor Hall, Buffalo, NY 14214-8033, USA and/or postprandial hyperglycemia [1]. DM has been defined as a group of diseases, rather than a single homogenous syndrome, caused by altered efficiency in the synthesis and release of insulin, resistance to the action of insulin, or both [1, 2]. Long-term occurrence of diabetes can cause further complications involving cardiovascular diseases, damage to blood vessels (angiopathy), and nerve damage (neuropathy). Other complications include damage to the renal system (nephropathy) and lower limb amputation due to impaired circulation. Diabetes has also been associated with dysfunction of various metabolic pathways and is often correlated with significant hypertension and dyslipidemia $[1,3]$.

Significant effects of DM/ diabetic nephropathy (DN) on small molecules have been reported, but there are only a few studies that have evaluated the impact of DM/DN on the pharmacokinetics (PK) of antibodies [4]. Although the prevalence of microalbuminuria and macroalbuminuria is significant with type 2 diabetes mellitus (T2DM), only a limited number of studies have evaluated the alteration in renal elimination and urinary concentrations of proteins and macromolecules such as $\operatorname{IgG}[5,6]$. The preclinical and clinical evidence for changes in protein clearance, including that of monoclonal antibodies, in $\mathrm{DM}$ and $\mathrm{DM} / \mathrm{DN}$ will be presented in this review, as well the potential mechanisms underlying these changes.

\section{Diabetes Mellitus}

Diabetes is classified as type 1 and type 2. Gestational diabetes is sometimes categorized as the third type but is specific for glucose intolerance during pregnancy [1,7]. Type 1 diabetes mellitus (T1DM) is due to autoimmune damage to the insulinsecreting islet cells and is caused by a mixture of genetic and non-genetic factors, usually leading to absolute insulin deficiency. With an absence of insulin in the blood, there is a 
subsequent increase in blood and urine glucose levels. This leads to the classical symptoms of polyuria, polydipsia, polyphagia, and weight loss [8]. T1DM occurs as an acute metabolic dysfunction with sudden onset in children, adolescents, or young adults. If untreated, it can lead to diabetic ketoacidosis and nonketotic hyperosmolar coma. Although the onset of T1DM is observed mostly before the age of 30 , in recent years, some older individuals with type 2 diabetes mellitus have been observed to develop immune system disorders, leading to the simultaneous development of T1DM. Worldwide, T1DM accounts for $5-10 \%$ of all patients with DM [9]. T2DM (formerly called non-insulin-dependent or adult-onset) is the more common type of diabetes, constituting 90-95\% of cases. T2DM manifests as insulin resistance which renders cells insensitive to the presence of glucose. This mostly occurs during middle age; however, childhood obesity is leading to increased prevalence in teenagers [9-11].

The various complications of diabetes including retinopathy, amputation after trauma, increased risk of atherosclerotic vascular disease, DN, and end-stage renal disease (ESRD) have made diabetes the major contributor to morbidity and mortality in society $[12,13]$. Diabetic nephropathy represents around $17 \%$ of the complications of diabetes and is the major cause of end-stage renal failure (ESRF) in Western societies [14]. Compared to T1DM, a greater percentage of patients with T2DM have complications leading to DN. This can be attributed to the fact that diabetes may have been present for several years before its diagnosis is established. Simultaneous presence of hypertension also increases the prevalence of microalbuminuria in T2DM [1].

As of 2012, around 21 million people have been diagnosed with diabetes in the USA, with another 8.1 million estimated to be undiagnosed [10]. Globally, in 2010, it was estimated that around 285 million people have been diagnosed with T2DM. It is estimated that the prevalence of T2DM will increase to around 500 million people worldwide by 2030 [11, 15]. The number of patients with diabetes has been increasing due to population growth and adverse social habits, including poor diet choices and decreased physical activity, leading to obesity [11]. In the USA, the total spending for diabetes treatment in 2012 was \$245 billion and the expenditure for ESRF was $\$ 32.9$ billion [16, 17], indicating significant societal health care impact.

\section{Diabetic Nephropathy}

DN represents a major microvascular complication of diabetes and is known to be the leading cause of ESRF $[12,18]$. DN is a progressive kidney disease caused by microvascular changes in the kidney glomeruli. It is characterized by increased elimination of serum proteins in the urine (proteinuria) with a subsequent decline in glomerular filtration rate (GFR). The earliest clinical symptom of DN is microalbuminuria (presence of low but significant amount $(\geq 30 \mathrm{mg} /$ day of albumin in the urine)). Without therapeutic intervention, around $80 \%$ of T1DM and $30 \%$ of T2DM patients progress to macroalbuminuria ( $\geq 300 \mathrm{mg}$ /day of albumin in the urine) over a period of 10-15 years. This is followed by a gradual decrease in the GFR, with ESRF subsequently occurring in $50 \%$ of T1DM and $20 \%$ of T2DM patients $[12,13]$. Commonly, hypertension and poor glycemic control frequently occur before macroalbuminuria occurs, although a small percentage of the diabetic population develops DN despite euglycemic control and normal blood pressure. The progression of DN has been classified into five stages (Table 1) in which a normal renal system proceeds to ESRF mediated by the structural and functional deterioration of the kidney [19, 20]. The earliest structural abnormality observed routinely in diabetic animals, as well as patients, is an increase in the thickness of the glomerular basement membrane (GBM) $[21,22]$. Changes in GBM thickness can occur even in the absence of albuminuria [22, 23]. However, as microalbuminuria persists and becomes more severe, there is a further increase in the GBM thickness, suggesting that there may be an association between protein leakage and progression of GBM thickening [22, 23].

Recently, it has been demonstrated that the podocytes also play an important role in the proteinuria observed in DM/DN and in the development of glomerulosclerosis [24, 25]. The strategic location of podocytes surrounding the GBM and glomerular capillaries allows the podocytes to significantly contribute to the protein efflux from the glomeruli into the urinary space within Bowman's capsule (Fig. 1). With early DN, structural alterations in podocytes can lead to widening of the attachment points to the GBM. This initial alteration can also occur without development of microalbuminuria [25]. Moreover, as DN becomes more severe, further damage to podocytes leads to complete detachment from the GBM and excretion into the urine. Focal segmental glomerulosclerosis and membranous nephropathy are associated with podocyte detachment and apoptosis [27, 28]. Podocytes were absent in the urine of healthy controls without albuminuria and chronic kidney failure diabetic patients. However, with microalbuminuria, a significant increase in the amount of podocytes in the urine occurred. The number of podocytes in urine further increased with macroalbuminuria. Other studies have also reported a decrease in the number/density of podocytes per glomerulus with increasing albuminuria. Since podocytes cannot regenerate, compensation for this loss does not occur. Although no direct relationship was observed in amounts of urinary albumin excretion and urinary podocytes, the trend in the data suggested that podocytes can be utilized as an important marker of DN [28]. Furthermore, podocyte-specific protein (nephrin) can be dysregulated in $\mathrm{DN}$, and the decrease in expression may be due to 
Table 1 Stages of diabetic nephropathy
Fig. 1 Alterations in glomerular basement membrane and podocytes with diabetes. In healthy glomeruli, the fenestrated endothelial cell layer, basement membrane, and podocyte foot processes form a strong filtration barrier which is impermeable to large molecular weight proteins. In diabetes, damage to podocytes and basement membrane leads to increase in sieving of molecules across the barrier, leading to proteinuria. [Figure modified from Nihalani and Susztak [26] and used with permission]

\begin{tabular}{|c|c|c|}
\hline Stage & Duration of diabetes & Manifestations \\
\hline 1 & 0 to $2-3$ years & $\begin{array}{l}\text { Renal hypertrophy of diabetic glomerulus and high filtration stage } \\
\text { - } \uparrow \text { Renal plasma flow } \\
\text { - } \uparrow \text { GFR } \\
\text { - } \leftrightarrow \text { UAE } \\
\text { - Reversible with treatment }\end{array}$ \\
\hline 2 & $2-3$ to 7 years & $\begin{array}{l}\text { Asymptomatic renal damage stage } \\
\text { - Changes in renal structure } \\
\text { ○ Mesangial and tubulointerstitial expansion } \\
\text { ○ } \uparrow \mathrm{GBM} \\
\text { - } \uparrow \text { GFR } \\
\text { - } \leftrightarrow \text { Blood pressure } \\
\text { - Microalbuminuria starts } \\
\text { - Good prognosis with treatment }\end{array}$ \\
\hline 3 & 7 to 15 years & $\begin{array}{l}\text { Early stage of diabetic nephropathy } \\
\text { - Intense changes in renal structure } \\
\text { - } \uparrow \text { Microalbuminuria } \\
\text { - } \uparrow \text { Blood pressure } \\
\text { - } \leftrightarrow \text { GFR }\end{array}$ \\
\hline 4 & 15 to 25 years & $\begin{array}{l}\text { Clinical diabetic nephropathy stage } \\
\text { - } \uparrow \uparrow \text { proteinuria (macroalbuminuria) } \\
\text { - Hypoalbuminemia and edema } \\
\text { - } \uparrow \uparrow \text { Blood pressure } \\
\text { - } \downarrow \text { GFR }\end{array}$ \\
\hline 5 & After 25 years & $\begin{array}{l}\text { End-stage renal failure disease stage } \\
\text { - } \uparrow \uparrow \text { Serum creatinine level } \\
\text { - } \uparrow \text { Blood urea nitrogen } \\
\text { - } \uparrow \uparrow \text { Blood pressure } \\
\text { - } \uparrow \uparrow \text { Edema } \\
\text { - Dialysis needed }\end{array}$ \\
\hline
\end{tabular}

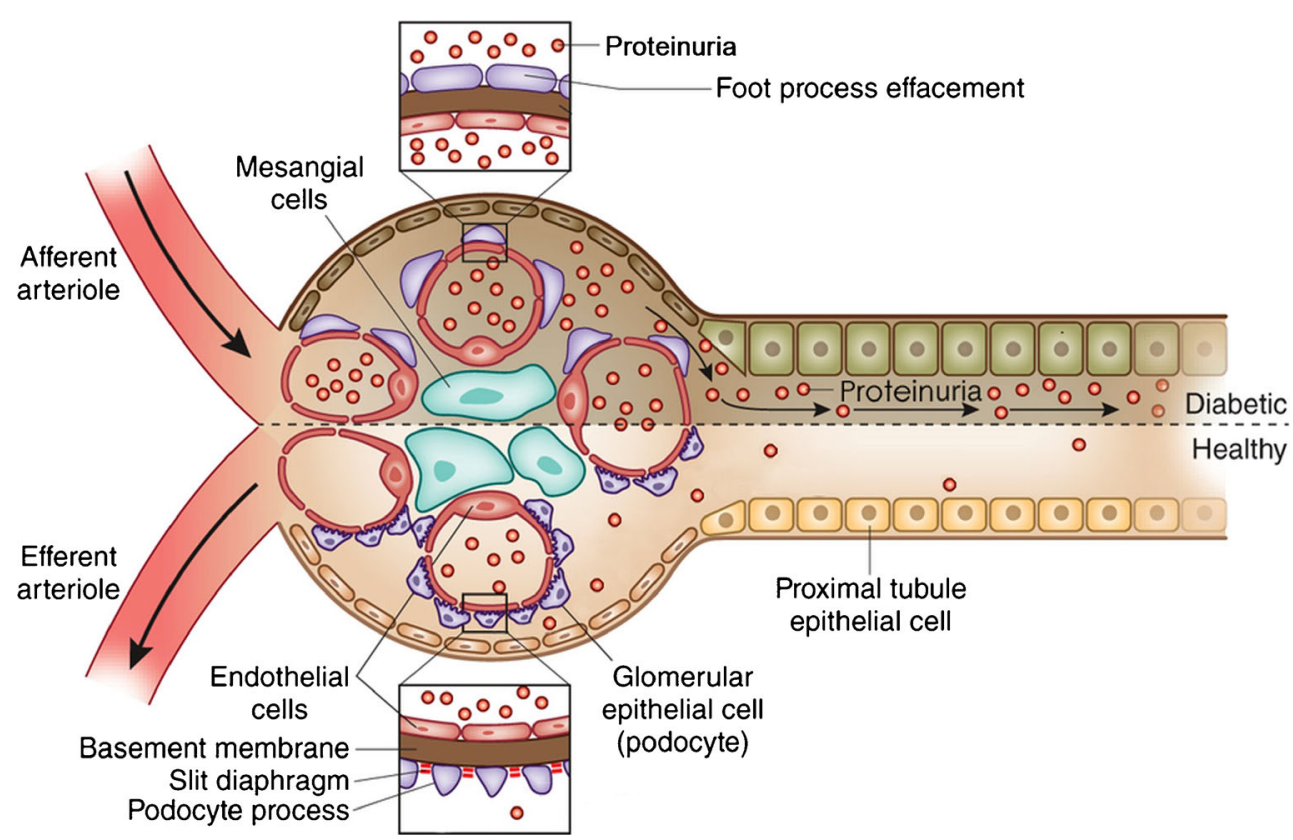


different regulatory factors $[29,30]$. Thus, the association between podocyte protein abnormalities and DN may contribute to proteinuria and eventually glomerulosclerosis.

The tubulointerstitium accounts for as much as $90 \%$ of kidney volume and changes in the tubulointerstitium in diabetes include thickening of the tubular basement membrane and tubular atrophy. Conventionally, changes due to glomerular injury and podocyte effacement have been described as the primary cause of renal disease progression. Changes in tubulointerstitium have been defined as a secondary reaction to elevated intratubular protein due to glomerular leakage [31, 32]. However, in some cases, tubular injury can also contribute further to glomerular damage which was observed with overexpression of vascular endothelial growth factor (VEGF)$\mathrm{A}$ in transgenic mice [33]. Overexpression of VEGF in the renal tubular system of rats led to tubular cyst formation along with interstitial fibrosis. Although the pathway involving the degeneration of tubules prior to glomerular sclerosis is possible, it is less frequent [34]. No clear correlation has been observed between tubular membrane thickening and renal impairment. On the other hand, significant correlations have been observed between interstitial expansions and magnitude of renal dysfunction and with albuminuria along with mesangial enlargement in both T1DM and T2DM [35-37].

Overall, the role of progressive glomerular injury along with changes in the tubulointerstitium in DN can be characterized by the following mechanisms: (a) self-sustained production of pro-inflammatory cytokines and growth factors (such as interferons, interleukins, lymphokines, and tumor necrosis factor) in glomerulus and tubulointerstitium; (b) increased filtered protein in the proximal tubule, leading to local hypoxia and peritubular damage; and (c) post-glomerular ischemia and atrophy due to sustained synthesis and release of vasoactive mediators [34, 35, 37].

\section{Pharmacokinetics of IgG and Monoclonal Antibodies (mAbs) in DM and DM/DN}

Antibodies (also known as immunoglobulins, Igs) are large molecular weight proteins, which are produced by the body's immune system when it detects antigens (bacteria, parasites, and viruses). Igs are classified based on the structure of their heavy chains as $\operatorname{IgA}$, IgD, $\operatorname{IgE}$, IgG, and IgM. IgG comprises around $80 \%$ of the Igs in human serum and is the predominant class of immunoglobulins. All of the approved therapeutic antibodies are IgGs $[38,39]$. Interest in the development of novel antibody drugs has been rapidly increasing over the last few decades, with more than 30 antibody products approved by the FDA and more than 100 in clinical development [40]. Although significant effects of DM/DN on small molecules have been reported, there are only a few studies that have evaluated the impact of DM/DN on the PK of mAbs [4].

\section{Role of FcRn}

Convection plays a major role in the movement of mAbs from the vascular compartment to the interstitial fluid, with a very minimal role for diffusion. mAbs present in the blood or interstitial fluid may enter cells via pinocytosis (receptor-mediated endocytosis, fluid-phase endocytosis). This represents an important pathway (Fig. 2) for antibody internalization into cells, since mAbs binding to the neonatal $\mathrm{Fc}$ receptor $(\mathrm{FcRn})$, also known as the Brambell receptor, protects $\mathrm{mAbs}$ from intracellular lysosomal degradation, since it results in recycling of mAbs to the plasma and/or interstitial space [39, 41, 42]. However, the protection via FcRn in the lysosome is a saturable process since FcRn is capacity limited (due to its finite expression). Hence, the elimination half-life of $\mathrm{mAbs}$ is concentration-dependent due to saturable FcRn binding [39, 41, 43, 44].

The catabolism of mAbs and endogenous proteins, including albumin and $\mathrm{IgG}$, occurs in various organs including liver, intestine, and tissues containing reticuloendothelial components such as spleen, skin, and muscle [45, 46]; these organs express FcRn that recycles mAbs [43]. The importance of FcRn has been highlighted in different studies using a FcRn knockout mouse animal model and demonstrating significantly different tissue distribution and concentrations of ${ }^{111}$ indium-labeled IgG, as compared to the control animals [47]. In another study, also using a mouse animal model, decreased spleen and renal uptake and increased hepatic uptake of IgG were observed in the absence of FcRn protection [48]. Interestingly, using ${ }^{125}$ iodine-labeled IgG (non-residualizing) instead of ${ }^{111}$ indium (residualizing) demonstrated a different

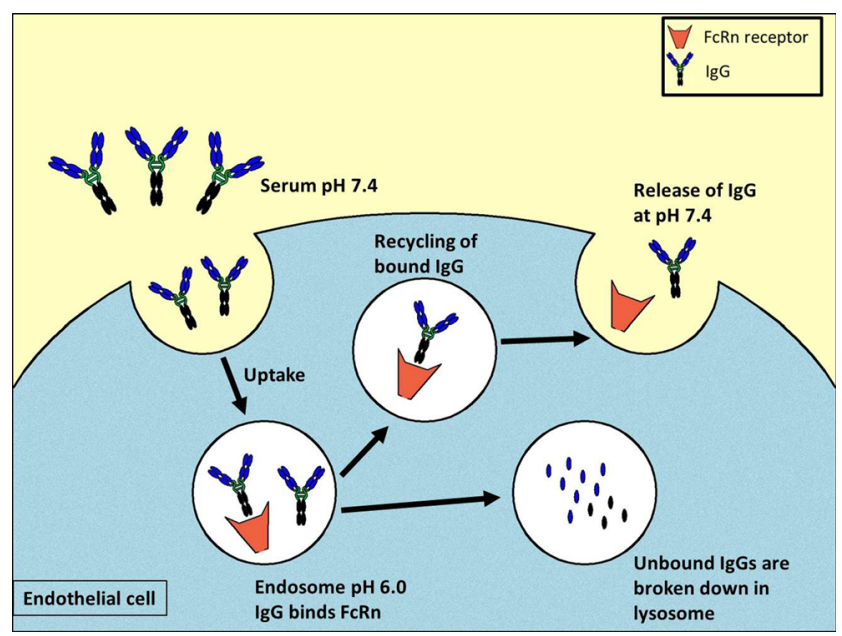

Fig. 2 Schematic diagram of the cellular processing of $\operatorname{IgG}$ in the presence and absence of FcRn binding protection. Antibodies enter the cell via pinocytosis. In the endosome, FcRn-protected $\mathrm{IgG}$ is sorted and recycled back to the extracellular space, while non-protected IgG undergoes lysosomal proteolytic degradation 


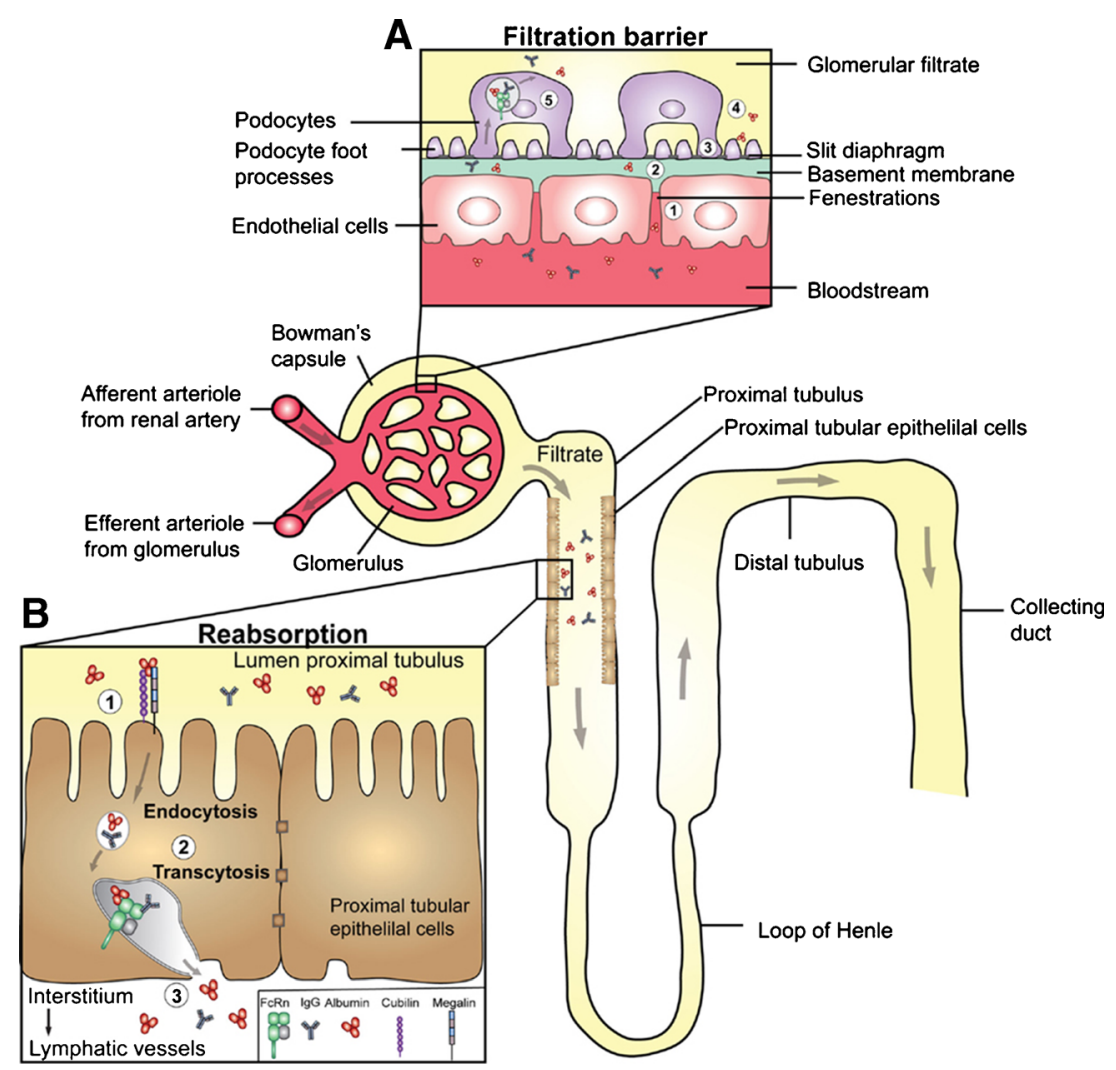

Fig. 3 Transport of IgG and albumin in the kidneys. Part $A$ depicts the filtration barrier of the glomerulus. The fenestrations between endothelial cells of the glomerular capillaries, the podocytes, and the foot processes of the podocytes (slit diaphragms) act as a sieving unit, which limits the movement of albumin and IgG across the membrane. Podocytes express FcRn, which helps with the transcytosis of IgG and albumin across the membrane, into the glomerular filtrate, to prevent clogging of the glomerular sieve. Part $B$ depicts the glomerular filtrate entering the proximal tubuli, where the proximal tubular epithelial cells lining the lumen of the tubuli are involved in reabsorption of albumin and $\operatorname{IgG}$, thus limiting their excretion through the urine. Proximal tubular epithelial cells also express the cubilin/megalin endocytic receptor complex that is involved in the uptake of albumin and IgG into the endosome. [Figure taken from Sand et al. 2014 [50]] trend where tissue distribution in FcRn knockout mice was similar to the control animal [49]. These differences would be due to the non-residualizing ability of iodine.

$\mathrm{FcRn}$ also plays a significant role in the renal elimination of endogenous proteins (albumin and IgG, Fig. 3) and mAbs [50-52]. The glomerular filtration barrier, which is made up of the fenestrated endothelium, the GBM, and the podocyte slit diaphragm, functions as a charge- and size-selective barrier. Blood is filtered through the glomerular capsule of the nephrons into the proximal convoluted tubule, where water and proteins are reabsorbed. A healthy adult filters roughly $180 \mathrm{~L}$ of plasma every $24 \mathrm{~h}$, across the two kidneys. This results in the filtration of more than $7 \mathrm{~kg}$ of albumin and $2 \mathrm{~kg}$ of $\operatorname{IgG}$ in humans $[50,53]$. Due to the fluid flow dynamics, significant amounts of serum proteins such as albumin and $\operatorname{IgG}$ can enter the GBM and accumulate behind the slit diaphragms of the podocytes; FcRn removes proteins that would otherwise clog the slit diaphragm [50-52]. The importance of podocyte FcRn is clearly demonstrated in studies where delayed clearance of IgG leads to serum-induced nephritis. Local nephrotoxic damage has been observed in diseases such as systemic lupus erythematosus, in which $\operatorname{IgG}$ and immune complexes are deposited at the glomerular barrier $[52,54]$.

Filtered plasma proteins are reabsorbed via receptormediated endocytic pathways by renal proximal tubule cells. The proximal tubule cells also express FcRn, and different studies have reported the significant role of $\mathrm{FcRn}$ in the uptake of albumin and $\operatorname{IgG}[55,56]$. Lack of FcRn expression abolished the tubular uptake of albumin and $\operatorname{IgG}[56,57]$. Such was also the case when normal mice were transplanted with FcRn deficient kidneys. FcRn-deficient mice had significantly higher urinary albumin excretion as compared to control mice. When these FcRn-deficient mice were transplanted with an FcRn-expressing kidney, increased serum levels of albumin along with decreased urinary albumin excretion was observed. On the other hand, minimal urinary excretion of $\mathrm{IgG}$ is observed in FcRn-deficient mice, but this increases to normal levels when the mice are transplanted with a single FcRn-expressing kidney. Thus, within the kidneys, FcRn is responsible for reclaiming albumin and restoring it to the systemic circulation. In contrast, the role of renal FcRn in the renal reabsorption and clearance of IgG is not clear [51]. 


\section{Role of Megalin and Cubilin}

Although FcRn may play a significant role in the renal tubular reabsorption of albumin and $\operatorname{IgG}$, other endocytic proteins may also play important roles. Many studies have observed uptake of albumin by the proximal tubular cells to be an active process, which also depends on the receptor complex consisting of cubilin and megalin (LPR2) endocytic receptors [58-60, 61•]. Megalin is a large membrane glycoprotein that belongs to the low-density lipoprotein receptor (LDLR) family $[60,61 \cdot, 62]$. Megalin is internalized with its ligands into endocytic compartments and then recycled to the cell surface [63]. Cubilin originally identified as the intestinal intrinsic factor B12 receptor [64] is a large glycoprotein that lacks a transmembrane and a cytoplasmic domain, so it needs to interact with other membrane proteins, such as megalin for endocytosis. The function of cubilin also depends on amnionless (AMN), a 38- to $50-\mathrm{kDa}$ transmembrane protein [61 $]$. In the proximal tubule, AMN colocalizes with cubilin and is essential for the trafficking of cubilin to the apical membrane. Megalin and cubilin are expressed in the plasma membrane and are involved in the endocytosis pathway for epithelial cells. [61•, 65]. In renal proximal tubule cells, cubilin forms a two-receptor complex with megalin, with megalin directing internalization of the complex and bound ligands $[61 \cdot, 65,66]$. Megalin is responsible for the reabsorption of nearly all filtered plasma proteins, in cooperation with cubilin; the complex plays a key role in the uptake of low molecular weight (MW) proteins, the intermediate MW protein albumin, as well as higher MW proteins such as $\operatorname{IgG}[67,68]$. Megalin-knockout mice develop low MW proteinuria and albuminuria $[62,69]$. Based on these findings, FcRn, megalin, and cubilin all contribute to proximal tubular reabsorption, where megalin-cubilin form a protein complex to internalize the protein, which then is taken into the lysosome where it can be broken down or protected via FcRn binding. In case of $\mathrm{IgG}$, renal vascular endothelial FcRn can remove IgG from the circulation into the interstitium, where IgG can be taken up by the tubular cells at their basolateral site, followed by transcytosis into the urine. This would help to provide the underlying tissue the necessary immunity against infectious agents [50,51].

\section{Effect of DM/DN on the Pharmacokinetics of IgG and $\mathrm{mAbs}$}

Although microalbuminuria and macroalbuminuria occur in T2DM, only a limited number of studies have evaluated the alteration in renal elimination and urinary concentrations of proteins and macromolecules such as $\operatorname{IgG}[5,6]$. T2DM patients have been reported to have 200-fold higher concentrations of $\operatorname{IgG} 2$ in urine [5], and increased renal elimination and urinary concentrations of IgM and $\operatorname{IgG}$ has been reported with T2DM and DN in Pima Indians [6]. In another study, the total clearance of adalimumab in patients with focal segmental glomerulosclerosis was reported to be two- to fivefold higher with disease progression, with non-renal clearance contributing more to the change in total clearance than renal clearance [70 ${ }^{\bullet}$. Additionally, diabetic co-morbidity in psoriatic patients resulted in a $28.7 \%$ higher oral clearance (CL/F) of ustekinumab [71]. Significant increases in the clearance of $8 \mathrm{C} 2$ (a murine monoclonal antibody) have been observed with type $1 \mathrm{DM}$ in streptozotocin-treated mice. These changes were positively correlated with changes in urinary albumin excretion and glomerular filtration rates [72].

Under normal conditions, only a fraction of proteins of molecular weight $>70 \mathrm{kDa}$ are filtered into the tubular lumen. The small percentage of proteins that cross into the lumen undergo tubular reabsorption by the epithelial cells of the proximal tubule. Hence, almost negligible amounts of mAbs are eliminated in the urine [73]. In $\mathrm{DM} / \mathrm{DN}$, there is an increase in the urinary elimination of intermediate molecular weight proteins (albumin) and high molecular proteins ( $\mathrm{mAbs}, \operatorname{IgA}, \mathrm{IgG}$ ). The increased elimination of these proteins is due to a significant increase in filtered load across the glomerular membrane (due to alterations in the permselectivity of the glomerular capillary wall) and from defects and/or saturation in the tubular reabsorption pathways. Many studies have evaluated the renal function changes with $\mathrm{DM} / \mathrm{DN}$ using neutral dextrans or Ficoll probes $[6,67,68,74]$. Significant increase in the filtration of the probes as well as proteins was observed, and the occurrence of proteinuria was attributed to the development of large pores in the GBM. This was accompanied by simultaneous changes in charge and size selectivity, which led to macroalbuminuria. Furthermore, as the filtered load increases with diabetes progression, the tubular reabsorption pathway becomes saturated. Some studies have also reported a decrease in the efficiency or dysfunction in the tubular reabsorption pathway. After endocytosis, excessive amounts of proteins can accumulate in the lysosomes of proximal tubule cells and can induce inflammation and fibrogenesis in the interstitium $[32,75,76]$.

We have recently evaluated the effect of T2DM and DN in Zucker diabetic fatty (ZDF) rats on the disposition of human IgG (hIgG), an antibody isotype, after its IV and subcutaneous (SC) administration [77••]. ZDF rats were treated with the anti-diabetic drug pioglitazone to evaluate the role of T2DM and DN on the pharmacokinetics of hIgG. The role of chronic kidney disease (CKD) was assessed using 5/6 nephrectomized Sprague Dawley rats. ZDF male control and obese diabetic rats and pioglitazone-treated diabetic ZDF rats were studied at ages 12-13 weeks (only DM was present) and at ages 2930 weeks (progression to DN). ZDF rats had significantly higher blood glucose concentrations and urinary albumin excretion compared to control rats. With pioglitazone treatment, diabetic animals became euglycemic, although the changes in urinary albumin excretion were incompletely reversed. 
Significant increases in the total clearance (2.5-fold) and renal clearance (100-fold) of hIgG were observed; however, the major increase in total clearance was due to increased nonrenal clearance. With the progression of the disease to DN, there were significant increases in urinary albumin excretion, as well as in the total and renal clearances of $\operatorname{IgG}$ (3.5-fold and 300 -fold, respectively) (Fig. 4). SC bioavailability of hIgG in all animal groups was high (>84 \%) and unchanged among groups. Pioglitazone treatment in the diabetic animals was able to reverse the changes in total clearance. However, the changes in renal clearance were incompletely reversed, similar to the changes observed with urinary albumin excretion. In the experimental CKD animals, hIgG clearance was unchanged
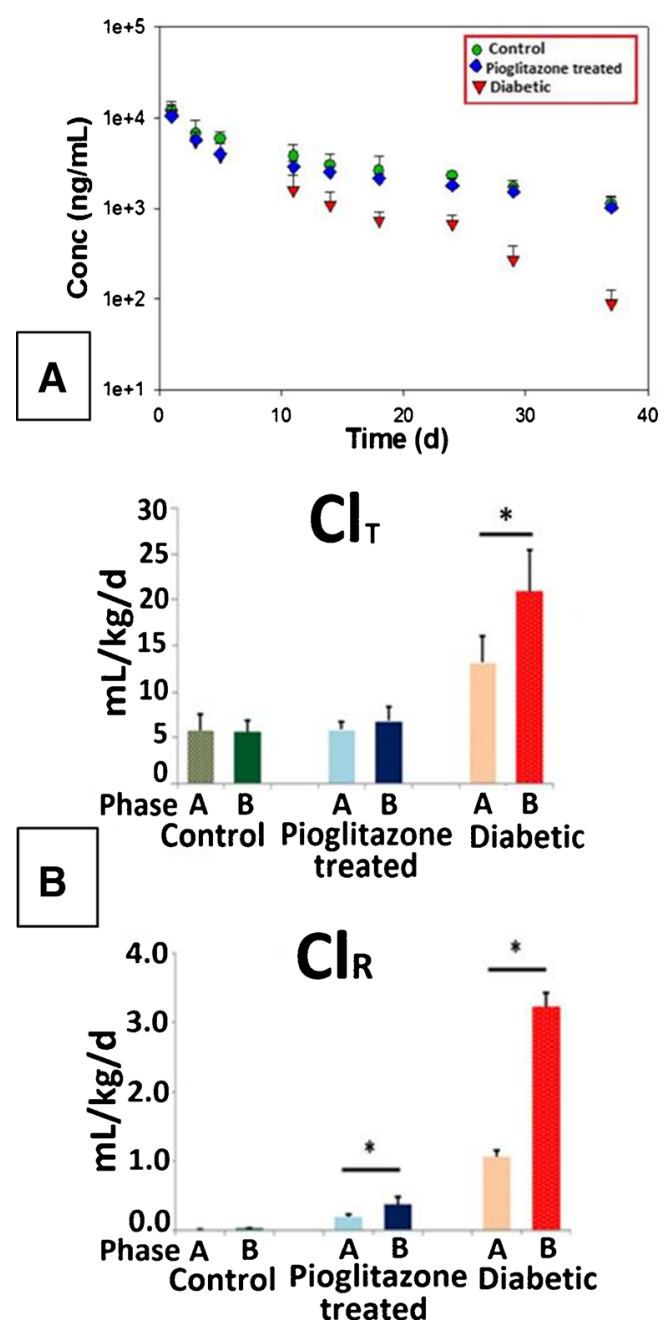

Fig. 4 a Plasma concentration-time profiles of human IgG in control, ZDF diabetic, and pioglitazone-treated ZDF rats after IV administration of $1 \mathrm{mg} / \mathrm{kg}$ at $12-13$ weeks of age (phase A) when only DM is present. b Total clearance and renal clearance as a fold change related to the control group after the administration of $1 \mathrm{mg} / \mathrm{kg} \mathrm{IgG}$ to control, ZDF diabetic, and pioglitazone-treated ZDF rats at ages of 12-13 weeks (when only $\mathrm{DM}$ is present; phase A) and 26-28 weeks (when DM/DN is present; phase B). Asterisk: significant differences between phase A and phase B were determined by ANOVA with a Tukey's test, $p<0.05 ; n=6-8$ animals per group (data from Chadha and Morris [77••]) compared with controls. In conclusion, the effect of T2DM on hIgG renal and catabolic clearances was characterized by an increased clearance of hIgG in ZDF diabetic animals that could be reversed by pioglitazone treatment. CKD had no significant effect on $\mathrm{hIgG}$ clearance. Our studies suggest that there may be increased clearance of monoclonal antibodies in poorly controlled diabetic subjects that demonstrate hyperglycemia $[77 \cdot \bullet]$.

\section{Mechanisms Involved in the Increased IgG and $\mathrm{mAb}$ Clearance in DM/DN}

\section{Altered Expression of FcRn, Megalin, and Cubilin}

Different studies have reported a decrease in megalin function with DM and obesity. Impairment of megalin function, even in the early stages of diabetes, has been observed in rat animal models as well as in patients [78-80]. Streptozotocin-induced diabetic rats had decreased protein expression of megalin at the apical membrane of proximal convoluted tubule cells. Megalin expression can be severely down-regulated due to protein overload in diabetes, via activation of the reninangiotensin system and increased transforming growth factor beta (TGF- $\beta$ ) and tumor necrosis factor alpha (TNF- $\alpha$ ) signaling in the lumen of the proximal tubular cells [80]. Treatment of diabetic rats with quinapril and candesartan (angiotensin converting enzyme inhibitors) restored the expression. Pioglitazone, at low doses, even without glycemic control, has been reported to normalize the renal concentrations of TNF- $\alpha$ and megalin [81]. Thus, impaired renal expression of megalin may not only inhibit the clearance of $\operatorname{IgG}$ antibodies from glomerular podocytes (thus causing local inflammation and glomerular damage) but also prevent the uptake and catabolism of IgG through the proximal tubule cells [61•]. Studies have observed decreased megalin mRNA expression in response to albumin overload in cell culture systems [82]. However, changes in megalin/cubilin expression with chronic kidney disease are controversial. Interestingly, certain studies with proteinuric mice did not observe any significant changes in megalin expression [83]. Megalin and cubilin may be regulated during nephrotic syndrome; effects might be associated with a decrease in expression to protect the proximal tubule from toxic accumulation or an increase in expression to fulfill their role as scavenger receptors [84]. Further studies evaluating the expression, activity, and regulation of megalin and cubilin may be able to shed more light on the changes associated with $\mathrm{DM} / \mathrm{DN}$ in their pathways.

The relationship between FcRn and antibody catabolism is well documented in the literature; however, there is no information regarding FcRn expression or function in DM/DN. The location of FcRn on glomerular epithelial cells, where IgG-FcRn interactions in the renal podocytes result in clearance of $\operatorname{IgG}$ from the glomerular basement membrane, and in 
renal proximal tubule epithelial cells, where it may be involved in endocytosis at the apical membrane $[55,56]$, suggest a role of FcRn in protein renal elimination. FcRndeficient mice have significantly higher urinary albumin excretion and lower serum concentrations, compared to control mice, and exhibit increased catabolism of IgG in tissues [85]. A study of familial hypercatabolic hypoproteinemia, which is a rare human syndrome, reported very low serum levels of IgG and albumin that correlated with abnormally low expression of FcRn, thus showing strong correlation between FcRn protein expression and albumin and $\mathrm{IgG}$ disposition [86].

\section{Non-Enzymatic Glycosylation of $\operatorname{Ig} G$}

Chronic hyperglycemia in DM leads to non-enzymatic glycation of proteins or advanced protein glycosylation, and glycosylation of $\mathrm{IgG}$ has been demonstrated to be increased in DM/DN [87-89]. This process involves non-enzymatic modification of tissue proteins by physiologic sugars through which sugar molecules become covalently attached to amino groups on the lysine residues or the $\mathrm{N}$-terminal amino acids of proteins to form a labile Schiff base [90]. This is followed by cross-linking of proteins, which leads to formation of advanced glycation end products (AGEs). These sugar-derived modification products play a significant role in the pathogenesis of diabetic complications, affecting renal function as well as tissue concentrations and metabolism [91]. Non-enzymatic modification of proteins causes alterations in charge, solubility, and conformation which lead to molecular dysfunction and disrupted interactions with other proteins [89, 92]. Hemoglobin, along with other proteins including $\mathrm{IgG}, \mathrm{IgA}$, $\mathrm{IgM}$, and albumin, undergo glycosylation in patients with DM. A positive correlation has been clinically observed between glycosylated hemoglobin, glycosylated albumin, and glycosylated $\operatorname{IgG}[89,93]$. Around $10 \%$ of the albumin in normal human serum can be glycosylated, which can cause a conformational change in human serum albumin and alter its functional properties [90]. Glycosylation of IgM leads to a significant decrease in its agglutination function, which could decrease the diabetic patient's resistance to infections [94]. Glycosylation of IgG from rabbit and human serum, as a result of in vitro glucose incubation, led to a marked decrease in the biological activity of $\mathrm{IgG}$, as determined in a microcomplement fixation test. Furthermore, inactivation of the specific antibody was dependent on incubation time and glucose concentration used for the process [95]. Also, long-term incubations of $\operatorname{IgG}$ led to the formation of heavy molecular weight aggregates, suggesting an AGE-like process [96]. Glycated IgG has altered binding to protein A, which can cause increased phagocytic engulfment of the antibody [97]. The presence of high affinity receptors for AGE-proteins has been observed in mouse macrophages, suggesting macrophage degradation of antibody is an in vivo mechanism for the removal of the antibody [98]. A study in mice has demonstrated a significant increase in the vascular clearance rate of glycated IgG, as compared to unglycated IgG [88].

In patients with DM, AGE-proteins are known to accumulate in glomerular basement membrane, mesangial cells, endothelial cells, and podocytes, resulting in the progression of DM to DN. Presence of AGE-proteins leads to increased oxidative stress and overproduction of different growth factors and cytokines [99]. This causes deterioration of the GBM endothelial layer and promotes podocyte cell detachment. Thus, the renal system becomes more susceptible to renal fibrosis, leading to increase in filtration of plasma proteins across GBM [89, 100, 101]. The renal function damage in DN by AGE can be reversed by pharmacological agents such as aminoguanidine, which reduces concentrations of AGEs. It significantly reduced urinary albumin elimination by around $90 \%$ and slowed the progression of nephropathy $[102,103]$. While increased glycosylation of IgG can occur in DM/DN, the role that this modified IgG plays in its increased clearance is unknown.

\section{Hypercatabolism of Proteins}

Under normal conditions, the fasting state in humans is characterized by release of glutamine and alanine from muscles and with the catabolism of branched chain amino acids (leucine, isoleucine, and valine) in muscle. This is associated with the replenishment of muscle nitrogen by the muscle uptake of branched chain amino acids in ingested protein. In diabetic patients, there is protein hypercatabolism, resulting in the increased uptake of alanine by the liver for gluconeogenesis and in accelerated branched chain amino acid breakdown in the muscles. There is reduced muscle uptake and concentrations of amino acids increase in the arterial blood. One of the primary reasons for this imbalance is due to the lack of insulin, which is prominent in T1DM. However, this hypercatabolism state is less frequent in T2DM where insulin stores are not compromised [104, 105]. However, exposure of tissues to chronic hyperglycemia acts as an initiating factor that can alter the metabolism state of the body by a number of potential mechanisms. Renal and non-renal cells are stimulated by hyperglycemia, which leads to over-activation and production of different cytokine factors that are responsible for structural and functional alterations in diabetes and DN. The metabolic changes include increase in reactive oxygen species and in inflammatory cytokines along with growth and apoptotic factors [106, 107].

\section{Role of Cytokines}

Cytokines are a group of low molecular weight soluble proteins and peptides, and many studies have evaluated the role of cytokines in modulating the disposition of mAbs and IgG, via changes in FcRn expression. Studies have observed DM/ 
DN progression to be closely associated with elevation of levels of IL-6 [108]. TNF- $\alpha$ has also been observed to directly regulate the mRNA and protein expression of FcRn. TNF- $\alpha$ is a member of the inflammatory cytokine family [107] that can activate various second messenger pathways, transcription factors, growth factors, cell adhesion molecules, and enzymes involved in the synthesis of other inflammatory mediators. Many studies have reported a consistent increase in TNF- $\alpha$ mRNA and protein expression in glomerular and proximal tubule cells of diabetic rats [109-112]. The increase in TNF- $\alpha$ led to a down-regulation of FcRn mRNA and protein expression in human retinal pigment epithelium cells [44]. However, TNF- $\alpha$ treatment of an intestinal epithelial cell line (macrophage-like THP-1) and of freshly isolated human monocytes resulted in the rapid up-regulation of FcRn gene expression. Treatment of TNF-stimulated THP-1 cells with a NF-kappaB specific inhibitor has resulted in down-regulation of mRNA and protein FcRn expression [113]. Based on the literature, it is not possible at this time to establish a correlation between the expression of TNF- $\alpha$ and FcRn regulation. TNF- $\alpha$ may have a differential role for stimulating or inhibiting FcRn pathways and modulating the disposition of antibodies. The role of cytokines in the regulation of the endocytosis proteins megalin and cubilin has not been defined, although with an increase in TGF- $\beta$ and TNF- $\alpha$ signaling pathways, a downregulation in the megalin protein expression has been observed in the proximal tubular cells [80]. The immunosuppressive drug myophenolate mofetil and anti-inflammatory drug pentoxifylline, that inhibit the transcription of the TNF- $\alpha$ gene, can largely prevent the development of albuminuria and glomerular injury in experimental DN. In addition, pentoxifylline modulates the expression of IL-1 $\beta$ and IL-6. Infliximab, an anti-TNF- $\alpha \mathrm{mAb}$, has also been investigated and can decrease urinary albumin excretion in streptozotocin-treated rats, an animal model of type I DM [114]. Therefore, inflammatory cytokines may play a role in the changes in renal function and protein catabolism observed in $\mathrm{DM} / \mathrm{DN}$, or alternatively changes in inflammatory cytokine protein levels may be a consequence of changes in renal function or hyperglycemia.

\section{Information Gap}

The mechanisms underlying the increased renal and catabolic clearances of IgG and monoclonal antibodies in DM/DN are currently unknown but may involve changes in the expression of FcRn and the endocytic proteins megalin and cubilin, increased glycosylation of high molecular weight proteins, and effects due to increased cytokine plasma and tissue concentrations. The clinical significance of these findings is also not known, but considering the high incidence rate of DM and DN ( $10 \%$ of the American population) and their high association with co-morbidities (heart disease, retinopathy, neuropathy, transplantation), the use of mAbs in these populations is likely for various indications [115-117] and may result in decreased plasma concentrations of mAbs impacting the pharmacodynamics of the mAbs.

\section{Conclusion}

Although research has focused on characterizing the pathophysiology of diabetes and the pharmacological interventions for diabetes, very little information is available regarding the effect of the disease on the pharmacokinetics and pharmacodynamics of mAbs, including the influence of diabetes on the catabolic and renal clearances of higher molecular weight proteins. This review addresses this information gap and evaluates the effect of DM and DM/DN on the disposition and clearance of IgG, a monoclonal antibody isotype, and the potential mechanisms contributing to the alterations in clearance.

Acknowledgments This study received support from the Center for Protein Therapeutics, University at Buffalo.

\section{Compliance with Ethical Standards}

Conflict of Interest The authors indicate no conflict of interest.

Human and Animal Rights and Informed Consent This article does not contain any studies with human or animal subjects performed by any of the authors.

\section{References}

Papers of particular interest, published recently, have been highlighted as:

- Of importance

•- Of major importance

1. American Diabetes Association. Standards of medical care in diabetes. Diabetes Care. 2014;37 Suppl 1:S14-80.

2. Polonsky KS. The past 200 years in diabetes. N Engl J Med. 2012;367(14):1332-40.

3. Sarwar N, Gao P, Seshasai SR, Gobin R, Kaptoge S, Di Angelantonio E, et al. Diabetes mellitus, fasting blood glucose concentration, and risk of vascular disease: a collaborative metaanalysis of 102 prospective studies. Lancet. 2010;375(9733): 2215-22.

4. Dostalek M, Akhlaghi F, Puzanovova M. Effect of diabetes mellitus on pharmacokinetic and pharmacodynamic properties of drugs. Clin Pharmacokinet. 2012;51(8):481-99.

5. Bakoush O, Tencer J, Tapia J, Rippe B, Torffvit O. Higher urinary IgM excretion in type 2 diabetic nephropathy compared to type 1 diabetic nephropathy. Kidney Int. 2002;61(1):203-8.

6. Lemley KV, Blouch K, Abdullah I, Boothroyd DB, Bennett PH, Myers BD, et al. Glomerular permselectivity at the onset of nephropathy in type 2 diabetes mellitus. J Am Soc Nephrol: JASN. 2000;11(11):2095-105. 
7. Kim C, Newton KM, Knopp RH. Gestational diabetes and the incidence of type 2 diabetes: a systematic review. Diabetes Care. 2002;25(10): 1862-8.

8. Cooke DW, Plotnick L. Type 1 diabetes mellitus in pediatrics. Pediatr Rev/ Am Acad Pediatr. 2008;29(11):374-84. quiz 85.

9. Daibetes Factsheet: World Health Organization; 2015. Available from: http://www.who.int/mediacentre/factsheets/fs312/en/.

10. National diabetes statistics report Atlanta, GA: Centers for Disease Control and Prevention; 2014. Available from: http://www.cdc. gov/diabetes/pubs/statsreport14/national-diabetes-report-web.pdf.

11. Wild S, Roglic G, Green A, Sicree R, King H. Global prevalence of diabetes: estimates for the year 2000 and projections for 2030 . Diabetes Care. 2004;27(5):1047-53.

12. Estacio RO, Schrier RW. Diabetic nephropathy: pathogenesis, diagnosis, and prevention of progression. Adv Intern Med. 2001;46: 359-408.

13. Ayodele OE, Alebiosu CO, Salako BL. Diabetic nephropathy-a review of the natural history, burden, risk factors and treatment. J Natl Med Assoc. 2004;96(11):1445-54.

14. Forbes JM, Cooper ME. Mechanisms of diabetic complications. Physiol Rev. 2013;93(1):137-88.

15. Guariguata L, Whiting D, Weil C, Unwin N. The International Diabetes Federation diabetes atlas methodology for estimating global and national prevalence of diabetes in adults. Diabetes Res Clin Pract. 2011;94(3):322-32.

16. Economic costs of diabetes in the U.S. in 2012: American Diabetes Association; 2013. Available from: http://care. diabetesjournals.org/content/early/2013/03/05/dc12-2625.

17. USRDS 2012 annual data report: atlas of chronic kidney disease and end-stage renal disease in the United States. National Institutes of Health, National Institute of Diabetes and Digestive and Kidney Diseases; 2012. Available from: http://www.usrds. org/adr.aspx.

18. Gross JL, de Azevedo MJ, Silveiro SP, Canani LH, Caramori ML, Zelmanovitz T. Diabetic nephropathy: diagnosis, prevention, and treatment. Diabetes Care. 2005;28(1):164-76.

19. Mogensen CE. Renal function changes in diabetes. Diabetes. 1976;25(2 SUPPL):872-9.

20. Weir G, Jameson JL, De Groot LJ. Diabetic nephropathy. In: Weir $\mathrm{G}$, editor. Endocrinology adult and pediatric: diabetes mellitus and obesity. 6 ed. Philadelphia: Elsevier; 2013.

21. Tervaert TW, Mooyaart AL, Amann K, Cohen AH, Cook HT, Drachenberg CB, et al. Pathologic classification of diabetic nephropathy. J Am Soc Nephrol: JASN. 2010;21(4):556-63.

22. Qi Z, Fujita H, Jin J, Davis LS, Wang Y, Fogo AB, et al. Characterization of susceptibility of inbred mouse strains to diabetic nephropathy. Diabetes. 2005;54(9):2628-37.

23. Steinke JM, Sinaiko AR, Kramer MS, Suissa S, Chavers BM, Mauer M, et al. The early natural history of nephropathy in type 1 diabetes: III. Predictors of 5-year urinary albumin excretion rate patterns in initially normoalbuminuric patients. Diabetes. 2005;54(7):2164-71.

24. Greka A, Mundel P. Cell biology and pathology of podocytes. Annu Rev Physiol. 2012;74:299-323.

25. Torbjornsdotter TB, Perrin NE, Jaremko GA, Berg UB. Widening of foot processes in normoalbuminuric adolescents with type 1 diabetes. Pediatr Nephrol. 2005;20(6):750-8.

26. Nihalani D, Susztak K. Sirt1-Claudin-1 crosstalk regulates renal function. Nat Med. 2013;19(11):1371-2.

27. Tojo A, Kinugasa S. Mechanisms of glomerular albumin filtration and tubular reabsorption. Int J Nephrol. 2012;2012:481520.

28. Nakamura T, Ushiyama C, Suzuki S, Hara M, Shimada N, Ebihara I, et al. Urinary excretion of podocytes in patients with diabetic nephropathy. Nephrol Dial Transplant Off Publ Eur Dial Transplant Assoc Eur Ren Assoc. 2000;15(9):1379-83.
29. Putaala H, Soininen R, Kilpelainen P, Wartiovaara J, Tryggvason $\mathrm{K}$. The murine nephrin gene is specifically expressed in kidney, brain and pancreas: inactivation of the gene leads to massive proteinuria and neonatal death. Hum Mol Genet. 2001;10(1):1-8.

30. Jim B, Ghanta M, Qipo A, Fan Y, Chuang PY, Cohen HW, et al. Dysregulated nephrin in diabetic nephropathy of type 2 diabetes: a cross sectional study. PLoS One. 2012;7(5):e36041.

31. Bonventre JV. Can we target tubular damage to prevent renal function decline in diabetes? Semin Nephrol. 2012;32(5):452-62.

32. Maezawa Y, Takemoto M, Yokote K. Cell biology of diabetic nephropathy: roles of endothelial cells, tubulointerstitial cells and podocytes. J Diabetes Investig. 2015;6(1):3-15.

33. Hakroush S, Moeller MJ, Theilig F, Kaissling B, Sijmonsma TP, Jugold $\mathrm{M}$, et al. Effects of increased renal tubular vascular endothelial growth factor (VEGF) on fibrosis, cyst formation, and glomerular disease. Am J Pathol. 2009;175(5):1883-95.

34. Kriz W, Hosser H, Hahnel B, Gretz N, Provoost AP. From segmental glomerulosclerosis to total nephron degeneration and interstitial fibrosis: a histopathological study in rat models and human glomerulopathies. Nephrol Dial Transplant Off Publ Eur Dial Transplant Assoc Eur Ren Assoc. 1998;13(11):2781-98.

35. Lane PH, Steffes MW, Fioretto P, Mauer SM. Renal interstitial expansion in insulin-dependent diabetes mellitus. Kidney Int. 1993;43(3):661-7.

36. Mauer SM, Steffes MW, Ellis EN, Sutherland DE, Brown DM, Goetz FC. Structural-functional relationships in diabetic nephropathy. J Clin Invest. 1984;74(4):1143-55.

37. Gilbert RE, Cooper ME. The tubulointerstitium in progressive diabetic kidney disease: more than an aftermath of glomerular injury? Kidney Int. 1999;56(5):1627-37.

38. Litman GW, Rast JP, Shamblott MJ, Haire RN, Hulst M, Roess W, et al. Phylogenetic diversification of immunoglobulin genes and the antibody repertoire. Mol Biol Evol. 1993;10(1):60-72.

39. Wang W, Wang EQ, Balthasar JP. Monoclonal antibody pharmacokinetics and pharmacodynamics. Clin Pharmacol Ther. 2008;84(5):548-58.

40. Reichert JM. Marketed therapeutic antibodies compendium. mAbs. 2012;4(3):413-5.

41. Lobo ED, Hansen RJ, Balthasar JP. Antibody pharmacokinetics and pharmacodynamics. J Pharm Sci. 2004;93(11):2645-68.

42. Ghetie V, Ward ES. Transcytosis and catabolism of antibody. Immunol Res. 2002;25(2):97-113.

43. Brambell FW, Hemmings WA, Morris IG. A theoretical model of gamma-globulin catabolism. Nature. 1964;203:1352-4.

44. van Bilsen $\mathrm{K}$, van Hagen PM, Bastiaans J, van Meurs JC, Missotten T, Kuijpers RW, et al. The neonatal Fc receptor is expressed by human retinal pigment epithelial cells and is downregulated by tumour necrosis factor-alpha. $\mathrm{Br} \mathrm{J}$ Ophthalmol. 2011;95(6):864-8.

45. Covell DG, Barbet J, Holton OD, Black CD, Parker RJ, Weinstein JN. Pharmacokinetics of monoclonal immunoglobulin G1, F(ab ')2, and Fab' in mice. Cancer Res. 1986;46(8):3969-78.

46. Ghetie V, Hubbard JG, Kim JK, Tsen MF, Lee Y, Ward ES. Abnormally short serum half-lives of $\operatorname{IgG}$ in beta 2 microglobulin-deficient mice. Eur J Immunol. 1996;26(3):690-6.

47. Yip V, Palma E, Tesar DB, Mundo EE, Bumbaca D, Torres EK, et al. Quantitative cumulative biodistribution of antibodies in mice: effect of modulating binding affinity to the neonatal $\mathrm{Fc}$ receptor. mAbs. 2014;6(3):689-96.

48. Jaggi JS, Carrasquillo JA, Seshan SV, Zanzonico P, Henke E, Nagel A, et al. Improved tumor imaging and therapy via i.v. IgG-mediated time-sequential modulation of neonatal $\mathrm{Fc}$ receptor. J Clin Invest. 2007;117(9):2422-30.

49. Garg A, Balthasar JP. Physiologically-based pharmacokinetic (PBPK) model to predict IgG tissue kinetics in wild-type and 
FcRn-knockout mice. J Pharmacokinet Pharmacodyn. 2007;34(5):687-709.

50. Sand KM, Bern M, Nilsen J, Noordzij HT, Sandlie I, Andersen JT. Unraveling the interaction between FcRn and albumin: opportunities for design of albumin-based therapeutics. Front Immunol. 2014;5:682

51. Sarav M, Wang Y, Hack BK, Chang A, Jensen M, Bao L, et al. Renal FcRn reclaims albumin but facilitates elimination of IgG. J Am S Nephrol: JASN. 2009;20(9):1941-52.

52. Akilesh S, Huber TB, Wu H, Wang G, Hartleben B, Kopp JB, et al. Podocytes use FcRn to clear IgG from the glomerular basement membrane. Proc Natl Acad Sci U S A. 2008;105(3):967-72.

53. DeFronzo RA, Davidson JA, Del Prato S. The role of the kidneys in glucose homeostasis: a new path towards normalizing glycaemia. Diabetes Obes Metab. 2012;14(1):5-14.

54. Rantala I. Glomerular epithelial cell endocytosis of immune deposits in the nephrotic rat. An ultrastructural immunoperoxidase study. Nephron. 1981;29(5-6):239-44.

55. Haymann JP, Levraud JP, Bouet S, Kappes V, Hagege J, Nguyen $\mathrm{G}$, et al. Characterization and localization of the neonatal Fc receptor in adult human kidney. J Am Soc Nephrol: JASN. 2000;11(4):632-9.

56. Kobayashi N, Suzuki Y, Tsuge T, Okumura K, Ra C, Tomino Y. FcRn-mediated transcytosis of immunoglobulin $\mathrm{G}$ in human renal proximal tubular epithelial cells. Am J Physiol Ren Physiol. 2002;282(2):F358-65.

57. Tenten V, Menzel S, Kunter U, Sicking EM, van Roeyen CR, Sanden SK, et al. Albumin is recycled from the primary urine by tubular transcytosis. J Am Soc Nephrol: JASN. 2013;24(12): 1966-80.

58. Aseem O, Smith BT, Cooley MA, Wilkerson BA, Argraves KM, Remaley AT, et al. Cubilin maintains blood levels of HDL and albumin. J Am Soc Nephrol: JASN. 2014;25(5):1028-36.

59. Amsellem S, Gburek J, Hamard G, Nielsen R, Willnow TE, Devuyst $\mathrm{O}$, et al. Cubilin is essential for albumin reabsorption in the renal proximal tubule. J Am Soc Nephrol: JASN. 2010;21(11): 1859-67.

60. Christensen EI, Birn H. Megalin and cubilin: multifunctional endocytic receptors. Nat Rev Mol Cell Biol. 2002;3(4):256-66.

61. Christensen EI, Birn H, Storm T, Weyer K, Nielsen R. Endocytic receptors in the renal proximal tubule. Physiology (Bethesda). 2012;27(4):223-36. An excellent current overview of the endocytic receptors megalin and cubilin.

62. De S, Kuwahara S, Saito A. The endocytic receptor megalin and its associated proteins in proximal tubule epithelial cells. Membranes. 2014;4(3):333-55.

63. Kaseda R, Iino N, Hosojima M, Takeda T, Hosaka K, Kobayashi A, et al. Megalin-mediated endocytosis of cystatin $\mathrm{C}$ in proximal tubule cells. Biochem Biophys Res Commun. 2007;357(4):1130-4.

64. Birn H, Verroust PJ, Nexo E, Hager H, Jacobsen C, Christensen EI, et al. Characterization of an epithelial approximately $460-\mathrm{kDa}$ protein that facilitates endocytosis of intrinsic factor-vitamin B12 and binds receptor-associated protein. J Biol Chem. 1997;272(42):26497-504.

65. Christensen EI, Verroust PJ, Nielsen R. Receptor-mediated endocytosis in renal proximal tubule. Pflugers Arch - Eur J Physiol. 2009;458(6):1039-48.

66. Kozyraki R, Fyfe J, Verroust PJ, Jacobsen C, Dautry-Varsat A, Gburek J, et al. Megalin-dependent cubilin-mediated endocytosis is a major pathway for the apical uptake of transferrin in polarized epithelia. Proc Natl Acad Sci U S A. 2001;98(22):12491-6.

67. Scandling JD, Myers BD. Glomerular size-selectivity and microalbuminuria in early diabetic glomerular disease. Kidney Int. 1992;41(4):840-6.

68. Ruggenenti P, Mosconi L, Sangalli F, Casiraghi F, Gambara V, Remuzzi G, et al. Glomerular size-selective dysfunction in
NIDDM is not ameliorated by ACE inhibition or by calcium channel blockade. Kidney Int. 1999;55(3):984-94.

69. Leheste JR, Rolinski B, Vorum H, Hilpert J, Nykjaer A, Jacobsen $\mathrm{C}$, et al. Megalin knockout mice as an animal model of low molecular weight proteinuria. Am J Pathol. 1999;155(4):1361-70.

70. Roberts BV, Susano I, Gipson DS, Trachtman H, Joy MS. Contribution of renal and non-renal clearance on increased total clearance of adalimumab in glomerular disease. J Clin Pharmacol. 2013;53(9):919-24. Clinical evidence for the effect of glomerular disease on the renal and non-renal clearance of the monoclonal antibody adalimumab.

71. Mercuri SR, Naldi L. Potential role of ustekinumab in the treatment of chronic plaque psoriasis. Biol Targets Ther. 2010;4:119-29.

72. Engler FA, Zheng B, Balthasar JP. Investigation of the influence of nephropathy on monoclonal antibody disposition: a pharmacokinetic study in a mouse model of diabetic nephropathy. Pharm Res. 2014;31(5):1185-93.

73. D'Amico G, Bazzi C. Pathophysiology of proteinuria. Kidney Int 2003;63(3):809-25.

74. Deckert T, Kofoed-Enevoldsen A, Vidal P, Norgaard K, Andreasen HB, Feldt-Rasmussen B. Size- and charge selectivity of glomerular filtration in type 1 (insulin-dependent) diabetic patients with and without albuminuria. Diabetologia. 1993;36(3): 244-51.

75. Phillips AO, Steadman R. Diabetic nephropathy: the central role of renal proximal tubular cells in tubulointerstitial injury. Histol Histopathol. 2002;17(1):247-52.

76. Remuzzi G, Bertani T. Pathophysiology of progressive nephropathies. N Engl J Med. 1998;339(20):1448-56.

77.• Chadha GS, Morris ME. Effect of type 2 diabetes mellitus and diabetic nephropathy on IgG pharmacokinetics and subcutaneous bioavailability in the rat. AAPS J. 2015;17(4):965-75. This publication from our group characterizes the effects of Type 2 diabetes and diabetic nephropathy on the pharmacokinetics of IgG in the Zucker diabetic fatty rat model, reporting increased renal and metabolic clearance of human IgG in this animal model.

78. Ogasawara S, Hosojima M, Kaseda R, Kabasawa H, YamamotoKabasawa K, Kurosawa H, et al. Significance of urinary fulllength and ectodomain forms of megalin in patients with type 2 diabetes. Diabetes Care. 2012;35(5):1112-8.

79. Tojo A, Onozato ML, Ha H, Kurihara H, Sakai T, Goto A, et al. Reduced albumin reabsorption in the proximal tubule of earlystage diabetic rats. Histochem Cell Biol. 2001;116(3):269-76.

80. Tojo A, Onozato ML, Kurihara H, Sakai T, Goto A, Fujita T. Angiotensin II blockade restores albumin reabsorption in the proximal tubules of diabetic rats. Hypertens Res Off J Jpn Soc Hypertens. 2003;26(5):413-9.

81. Toblli JE, Cao G, Giani JF, Angerosa M, Dominici FP, GonzalezCadavid NF. Antifibrotic effects of pioglitazone at low doses on the diabetic rat kidney are associated with the improvement of markers of cell turnover, tubular and endothelial integrity, and angiogenesis. Kidney Blood Press Res. 2011;34(1):20-33.

82. Caruso-Neves C, Pinheiro AA, Cai H, Souza-Menezes J, Guggino WB. PKB and megalin determine the survival or death of renal proximal tubule cells. Proc Natl Acad Sci U S A. 2006;103(49): $18810-5$.

83. Lee D, Gleich K, Fraser SA, Katerelos M, Mount PF, Power DA. Limited capacity of proximal tubular proteolysis in mice with proteinuria. Am J Physiol Ren Physiol. 2013;304(7):F1009-19.

84. Nielsen R, Mollet G, Esquivel EL, Weyer K, Nielsen PK, Antignac C, et al. Increased lysosomal proteolysis counteracts protein accumulation in the proximal tubule during focal segmental glomerulosclerosis. Kidney Int. 2013;84(5):902-10.

85. Chen N, Wang W, Fauty S, Fang Y, Hamuro L, Hussain A, et al. The effect of the neonatal $\mathrm{Fc}$ receptor on human $\mathrm{IgG}$ biodistribution in mice. mAbs. 2014;6(2):502-8. 
86. Waldmann TA, Terry WD. Familial hypercatabolic hypoproteinemia. A disorder of endogenous catabolism of albumin and immunoglobulin. J Clin Invest. 1990;86(6):2093-8.

87. Kaneshige H. Nonenzymatic glycosylation of serum $\mathrm{IgG}$ and its effect on antibody activity in patients with diabetes mellitus. Diabetes. 1987;36(7):822-8.

88. Kennedy DM, Skillen AW, Self CH. Glycation increases the vascular clearance rate of IgG in mice. Clin Exp Immunol. 1993;94(3):447-51.

89. Mistry K, Kalia K. Non enzymatic glycosylation of IgG and their urinary excretion in patients with diabetic nephropathy. Indian J Clin Biochem: IJCB. 2009;24(2):159-65.

90. Shaklai N, Garlick RL, Bunn HF. Nonenzymatic glycosylation of human serum albumin alters its conformation and function. J Biol Chem. 1984;259(6):3812-7.

91. Brownlee M. Advanced protein glycosylation in diabetes and aging. Annu Rev Med. 1995;46:223-34.

92. Goh SY, Cooper ME. Clinical review: the role of advanced glycation end products in progression and complications of diabetes. J Clin Endocrinol Metab. 2008;93(4):1143-52.

93. Kalia K, Sharma S, Mistry K. Non-enzymatic glycosylation of immunoglobulins in diabetic nephropathy. Clin Chim Acta Int J Clin Chem. 2004;347(1-2):169-76.

94. Hammes HP, Kiefel V, Laube H, Federlin K. Impaired agglutination of IgM resulting from non-enzymatic glycation in diabetes mellitus. Diabetes Res Clin Pract. 1990;9(1):37-42.

95. Dolhofer R, Siess EA, Wieland OH. Nonenzymatic glycation of immunoglobulins leads to an impairment of immunoreactivity. Biol Chem Hoppe Seyler. 1985;366(4):361-6.

96. Dolhofer-Bliesener R, Gerbitz KD. Effect of nonenzymatic glycation on the structure of immunoglobulin G. Biol Chem Hoppe Seyler. 1990;371(8):693-7.

97. Dolhofer-Bliesener R, Gerbitz KD. Impairment by glycation of immunoglobulin G Fc fragment function. Scand J Clin Lab Invest. 1990;50(7):739-46.

98. Vlassara H, Brownlee M, Cerami A. High-affinity-receptormediated uptake and degradation of glucose-modified proteins: a potential mechanism for the removal of senescent macromolecules. Proc Natl Acad Sci U S A. 1985;82(17):5588-92.

99. Fukami K, Yamagishi S, Ueda S, Okuda S. Role of AGEs in diabetic nephropathy. Curr Pharm Des. 2008;14(10):946-52.

100. Mohan S, Kalia K, Mannari J. Association between urinary IgG and relative risk for factors affecting proteinuria in type 2 diabetic patients. Indian J Clin Biochem: IJCB. 2012;27(4):333-9.

101. Araki S, Haneda M, Koya D, Isshiki K, Kume S, Sugimoto T, et al. Association between urinary type IV collagen level and deterioration of renal function in type 2 diabetic patients without overt proteinuria. Diabetes Care. 2010;33(8):1805-10.

102. Soulis-Liparota T, Cooper M, Papazoglou D, Clarke B, Jerums G. Retardation by aminoguanidine of development of albuminuria, mesangial expansion, and tissue fluorescence in streptozocininduced diabetic rat. Diabetes. 1991;40(10):1328-34.
103. Vasan S, Foiles PG, Founds HW. Therapeutic potential of AGE inhibitors and breakers of AGE protein cross-links. Expert Opin Investig Drugs. 2001;10(11):1977-87.

104. Felig P, Wahren J, Sherwin R, Palaiologos G. Amino acid and protein metabolism in diabetes mellitus. Arch Intern Med. 1977;137(4):507-13.

105. Abu-Lebdeh HS, Nair KS. Protein metabolism in diabetes mellitus. Bailliere Clin Endocrinol Metab. 1996;10(4):589-601.

106. Elmarakby AA, Sullivan JC. Relationship between oxidative stress and inflammatory cytokines in diabetic nephropathy. Cardiovasc Ther. 2012;30(1):49-59.

107. Navarro-Gonzalez JF, Mora-Fernandez C. The role of inflammatory cytokines in diabetic nephropathy. J Am Soc Nephrol: JASN. 2008;19(3):433-42.

108. Mirza S, Hossain M, Mathews C, Martinez P, Pino P, Gay JL, et al. Type 2-diabetes is associated with elevated levels of TNF-alpha, IL-6 and adiponectin and low levels of leptin in a population of Mexican Americans: a cross-sectional study. Cytokine. 2012;57(1):136-42.

109. Gao X, Picchi A, Zhang C. Upregulation of TNF-alpha and receptors contribute to endothelial dysfunction in Zucker diabetic rats. Am J Biomed Sci. 2010;2(1):1-12.

110. Yang J, Park Y, Zhang H, Gao X, Wilson E, Zimmer W, et al. Role of MCP-1 in tumor necrosis factor-alpha-induced endothelial dysfunction in type 2 diabetic mice. Am J Physiol Heart Circ Physiol. 2009;297(4):H1208-16.

111. Navarro JF, Milena FJ, Mora C, Leon C, Claverie F, Flores C, et al. Tumor necrosis factor-alpha gene expression in diabetic nephropathy: relationship with urinary albumin excretion and effect of angiotensin-converting enzyme inhibition. Kidney Int Suppl. 2005;99:S98-102.

112. DiPetrillo K, Gesek FA. Pentoxifylline ameliorates renal tumor necrosis factor expression, sodium retention, and renal hypertrophy in diabetic rats. Am J Nephrol. 2004;24(3):352-9.

113. Liu X, Ye L, Christianson GJ, Yang JQ, Roopenian DC, Zhu X. NF-kappaB signaling regulates functional expression of the MHC class I-related neonatal $\mathrm{Fc}$ receptor for $\mathrm{IgG}$ via intronic binding sequences. J Immunol. 2007;179(5):2999-3011.

114. Moriwaki Y, Inokuchi T, Yamamoto A, Ka T, Tsutsumi Z, Takahashi S, et al. Effect of TNF-alpha inhibition on urinary albumin excretion in experimental diabetic rats. Acta Diabetol. 2007;44(4):215-8.

115. Boni-Schnetzler M, Donath MY. How biologics targeting the IL-1 system are being considered for the treatment of type 2 diabetes. Br J Clin Pharmacol. 2012;76(2):263-8.

116. Cavelti-Weder C, Babians-Brunner A, Keller C, Stahel MA, KurzLevin M, Zayed H, et al. Effects of gevokizumab on glycemia and inflammatory markers in type 2 diabetes. Diabetes Care. 2012;35(8):1654-62.

117. Rissanen A, Howard CP, Botha J, Thuren T. Effect of anti-IL-1beta antibody (canakinumab) on insulin secretion rates in impaired glucose tolerance or type 2 diabetes: results of a randomized, placebocontrolled trial. Diabetes Obes Metab. 2012;14(12):1088-96. 